\title{
GMR
}

\section{mRNA and protein expression levels of four candidate genes for ear size in Erhualian and Large White pigs}

\author{
L.C. Zhang ${ }^{1 *}$, J. Liang ${ }^{2 *}$, L. Pu ${ }^{3 *}$, Y.B. Zhang ${ }^{1}$, L.G. Wang ${ }^{1}$, X. Liu ${ }^{1}$, \\ H. Yan' ${ }^{1}$ L.X. Wang ${ }^{1}$
}

${ }^{1}$ Key Laboratory of Farm Animal Genetic Resources and Germplasm Innovation, Ministry of Agriculture/Institute of Animal Science,

Chinese Academy of Agricultural Sciences, Beijing, China

${ }^{2}$ College of Animal Science and Veterinary Medicine,

Tianjin Agricultural University, Tianjin, China

${ }^{3}$ Laboratory of Animal Genetics and Breeding,

College of Animal Science and Technology, Guangxi University, Nanning, China

*These authors contribute to this study.

Corresponding authors: L.C. Zhang / L.X. Wang

E-mail: zhlchias@163.com / iaswlx@263.net

Genet. Mol. Res. 16 (2): gmr16029252

Received September 12, 2016

Accepted February 17, 2017

Published April 13, 2017

DOI http://dx.doi.org/10.4238/gmr16029252

Copyright (C 2017 The Authors. This is an open-access article distributed under the terms of the Creative Commons Attribution ShareAlike (CC BY-SA) 4.0 License.

\begin{abstract}
Porcine ear size is an important characteristic for distinguishing among pig breeds. In a previous genome-wide association study of porcine ear size, LEM domain-containing 3 (LEMD3), methionine sulfoxide reductase B3 (MSRB3), high mobility group AThook 2 (HMGA2), and Wnt inhibitory factor 1 (WIF1) were implicated as important candidate genes for ear size. This study investigated the expression levels of four candidate genes for ear size in Erhualian and Large White pigs. Ten Erhualian pigs with large ears and eight Large White pigs with small ears at 60 days of age were examined. The mRNA expression levels of the four candidate genes were quantified by real-time polymerase chain reaction. WIF1 mRNA expression
\end{abstract}

Genetics and Molecular Research 16 (2): gmr16029252 
was significantly higher in Large White than in Erhualian pigs $(\mathrm{P}<$ 0.05), whereas the expression levels of the other three genes were not significantly different between the two breeds. The protein expression levels of the four genes were analyzed using western blot. WIF1 protein expression was significantly higher in Large White than in Erhualian pigs $(\mathrm{P}<0.01)$, whereas MSRB3 protein expression was significantly higher in Erhualian than in Large White pigs $(\mathrm{P}<0.05)$. There were no significant differences between the two breeds in residual protein expression. These results suggest that WIFl is the main causal gene for ear size in pigs.

Key words: Gene expression; HMGA2; LEMD3; MSRB3; Pig; WIF1

\section{INTRODUCTION}

Porcine ear shape (size and erectness) is regarded as an important characteristic for distinguishing among pig breeds (Rothschild and Ruvinsky, 1998). Many studies have focused on the molecular mechanisms that determine ear size and erectness in pigs. Quantitative trait locus (QTL) mapping studies have discovered the QTLs for porcine ear erectness in Sus scrofa chromosomes (SSC) 1, 5, 6, 7, 9, and 12 (Guo et al., 2004; Wei et al., 2007; Ma et al., 2009). Moreover, QTLs for porcine ear size have been mapped to SSC 1, 4, 5, 6, 7, 8, 9, 11, 12, 16, and X (Wei et al., 2007; Ma et al., 2009). On SSC7, G32E in the PPARD gene has been identified as the causal mutation for porcine ear size (Ren et al., 2011; Duan et al., 2013); however, the causal gene for porcine ear size on SSC5 has not been identified. Therefore, it is important to study the candidate genes on SSC5 for porcine ear size to understand the molecular mechanisms of ear diversity in pigs.

In our previous genome-wide association study, LEM domain-containing 3 (LEMD3) and Wnt inhibitory factor 1 (WIFl) were identified as important candidate genes for porcine ear size (Zhang et al., 2014). Methionine sulfoxide reductase B3 (MSRB3) is adjacent to the most significant single nucleotide polymorphism that is associated with porcine ear size (Zhang et al., 2014), and studies in dogs have found that MSRB3 may be related to ear morphology (Boyko et al., 2010; Vaysse et al., 2011). Furthermore, porcine ear size QTL fine-mapping on SSC5 suggests that HMGA2 is involved in ear size (Wei et al., 2007; Li et al., 2012). Hence, previous studies have identified the possible causal genes for porcine ear size on SSC5 as the four candidate genes WIF1, HMGA2, LEMD3, and MSRB3; however, little is known about the mRNA and protein expression levels of HMGA2, LEMD3, MSRB3, and WIF1 in pig ear tissues. Erhualian pigs have big, floppy ears (Zhang et al., 1986), and the breed is a good model with which to study ear morphology. In this study, we evaluated the mRNA and protein expression levels of the above four candidate genes in Erhualian and Large White pigs.

\section{MATERIAL AND METHODS}

\section{Sampling and data collection}

Eight Large White and 10 Erhualian pigs at 60 days of age were obtained from the Institute of Animal Science, Chinese Academy of Agricultural Sciences, and the Chuying

Genetics and Molecular Research 16 (2): gmr16029252 
Agro-Pastoral Group Co. Ltd., respectively. After slaughter, we removed the entire external left ear, traced the shape of each ear on plotting paper to calculate its area, and collected samples for mRNA and protein extraction. All of the animals used in the study were treated in accordance with the guidelines for the use of experimental animals established by the Council of China, and the animal experiments were approved by the Science Research Department of the Institute of Animal Science, Chinese Academy of Agricultural Sciences (Beijing, China).

\section{RNA isolation, cDNA production, and quantitative real-time polymerase chain reaction (PCR)}

Total RNA was isolated from the tissue samples using an RNAprep Pure Tissue Kit (Tiangen, China) according to the manufacturer's instructions. Extracted RNA was eluted in water and quantified spectrophotometrically at an A260/280 ratio using a NanoDrop UV-Vis spectrophotometer (Thermo Scientific). The cDNA was amplified using RNA (1 mg) and a PrimeScript ${ }^{\mathrm{TM}} \mathrm{RT}$ reagent kit (TaKaRa, Japan), according to the manufacturer's instructions.

Gene mRNA expression levels were assessed by quantitative real-time PCR (QPCR) using a 7900HT Fast Real-Time PCR System (Applied Biosystems). $\beta$-actin was used as an endogenous control to normalize the target gene expression. The primer sequences are listed in Table 1. For the QPCR analysis, $1 \mu \mathrm{L}$ cDNA was used with $7.5 \mu \mathrm{L} \mathrm{SYBR}^{\circledR}$ Select Master Mix (Applied Biosystems), $0.5 \mu \mathrm{L}$ forward primer, $0.5 \mu \mathrm{L}$ reverse primer, and $5.5 \mu \mathrm{L}$ RNase-free $\mathrm{H}_{2} \mathrm{O}$. Each QPCR cycle was conducted as follows: $50^{\circ} \mathrm{C}$ for $2 \mathrm{~min}, 95^{\circ} \mathrm{C}$ for $5 \mathrm{~min}, 95^{\circ} \mathrm{C}$ for $10 \mathrm{~s}$, and $60^{\circ} \mathrm{C}$ for 1 min for 40 cycles. Relative quantification was calculated using the $2^{-\Delta \Delta \mathrm{Ct}}$ method (Livak and Schmittgen, 2001).

Table 1. Primers used for quantitative real-time polymerase chain reaction amplifications of WIF1, LEMD3, HMGA2, and MSRB3.

\begin{tabular}{|c|c|c|c|}
\hline Gene & Accession No. & Primers & Product size (bp) \\
\hline \multirow[t]{2}{*}{ WIF1 } & \multirow[t]{2}{*}{ XM_003481651 } & 5'-GAGTGCTCATAGGGTTTGAAGAAGA-3' & \multirow[t]{2}{*}{136} \\
\hline & & 5'-CAGGTGAAATTCATGGAATGGA-3' & \\
\hline \multirow[t]{2}{*}{ LEMD3 } & \multirow[t]{2}{*}{ XM_003126352 } & 5'-GGTTATTGTTGTTGTGCTTAGGTGTAG-3' & \multirow[t]{2}{*}{95} \\
\hline & & 5'-CTGCCTTGTTTCCTCTTCTTCTTT-3' & \\
\hline \multirow[t]{2}{*}{ HMGA2 } & \multirow[t]{2}{*}{ JF748727 } & 5'-AGCCGTCCACTTCAGCCC-3' & \multirow[t]{2}{*}{129} \\
\hline & & 5'-TGGGTCTTCCCCTTGGTCTC-3' & \\
\hline \multirow[t]{2}{*}{ MSRB3 } & \multirow[t]{2}{*}{ KP772260.1 } & 5'-CCTCAGGGTCATGTAGGGATAAA-3' & \multirow[t]{2}{*}{155} \\
\hline & & 5'-TCCAGGATCTTTGTGATGTGTATATT-3' & \\
\hline \multirow[t]{2}{*}{$\beta$-actin } & \multirow[t]{2}{*}{ DQ452569 } & 5'-GGACTTCGAGCAGGAGATGG-3' & \multirow[t]{2}{*}{138} \\
\hline & & 5'-AGGAAGGAGGGCTGGAAGAG-3' & \\
\hline
\end{tabular}

\section{Protein isolation and western blotting}

The protein expression levels were assessed by western blotting using a Mini TransBlot $^{\circledR}$ System (BIO-RAD). Ear tissue was ground into powder in liquid nitrogen and lysed with radioimmunoprecipitation assay buffer (Beyotime, China). The mixture was then supplemented with protease inhibitor (Pierce, USA) and centrifuged to obtain the total protein. Protein quantification was achieved by conducting a bicinchoninic acid assay. Five primary rabbit monoclonal or polyclonal antibodies (Abcam, UK) were used for western blotting: Anti-beta Actin antibody (ab8227), Anti-MSRB3 antibody (ab180584), Anti-WIF1 antibody (ab155101), Anti-HMGA2 antibody (ab109329), and Anti-LEMD3 antibody (ab124148). The 
$\beta$-actin protein was used as an endogenous control to normalize the target gene expression. After separation by $10 \%$ sodium dodecyl sulfate polyacrylamide gel electrophoresis, the protein bands were transferred onto a polyvinylidene difluoride membrane (Cell Signaling Technology Inc., USA). The membrane was blocked in defatted milk and incubated at $4{ }^{\circ} \mathrm{C}$ overnight. The membrane was then incubated with the primary antibody at a 1/1000 dilution for $1 \mathrm{~h}$. Two secondary antibodies, IRDye 800 goat Anti-rabbit IgG (green) and IRDye 680 goat Anti-rabbit IgG (red) (LI-COR Biosciences, USA) were used for WIF1, LEMD3, HMGA2, and $\beta$-actin detection at a $1 / 1000$ dilution for $1 \mathrm{~h}$. The protein bands were visualized using chemiluminescence reagents (Millipore, USA), with excitation wavelengths under $800 \mathrm{~nm}$ (green) and $700 \mathrm{~nm}$ (red). For detecting MSRB3, a secondary antibody, Fluorescein goat Antirabbit IgG antibody (Vector, USA), and a BeyoECL Plus kit (Beyotime), were used. Optical density was analyzed using Quantity One ${ }^{\circledR} 4.62$ software (BIO-RAD).

\section{Statistical analysis}

To statistically determine any significant differences, the relative mean expression levels and standard deviations were compared by Student $t$-test using SAS version 8.2 (SAS, 2001). All of the figures were plotted using Microsoft Office.

\section{RESULTS}

\section{Erhualian pigs had lower body weights but larger ears than Large White pigs}

The mean body weights of the Erhualian and Large White pigs were $9.63 \mathrm{~kg}$ and $22.61 \mathrm{~kg}$, respectively (Table 2), and their mean ear sizes were $127 \mathrm{~cm}^{2}$ and $88.54 \mathrm{~cm}^{2}$, respectively. Although the Erhualian pigs had a 12.98-kg lower mean body weight than the Large White pigs $(\mathrm{P}<0.0001)$, their ears were significantly larger than those of the Large White pigs $(\mathrm{P}<0.0001)$.

\section{Table 2. Phenotypic characteristics of Erhualian and Large White pigs.}

\begin{tabular}{l|l|c|c|c}
\hline Trait & Breed & $\mathrm{N}$ & Mean \pm SD $\left(\mathrm{cm}^{2}\right)$ & P value \\
\hline \multirow{2}{*}{ Ear size } & Erhualian & 10 & $127.00 \pm 10.18$ & $<0.0001$ \\
\cline { 2 - 5 } & Large White & 8 & $88.54 \pm 7.35$ & \\
\hline \multirow{2}{*}{ Body weight } & Erhualian & 10 & $9.63 \pm 2.03$ & $<0.0001$ \\
\cline { 2 - 4 } & Large White & 8 & $22.61 \pm 2.20$ & \\
\hline
\end{tabular}

\section{WIF1 transcript levels were higher in Large White pigs' ears than in Erhualian pigs' ears}

The expression levels of the four genes were similar (Table 3 and Figure 1). No significant differences were observed for LEMD3, HMGA2, or MSRB3, but WIF1 mRNA expression was significantly higher (two-fold) in Erhualian pigs than in Large White pigs ( $\mathrm{P}$ $<0.05$ ). We detected WIF1 mRNA expression in the livers and muscles of both the Erhualian and Large White pigs, although this was not significantly different (Figure 2). These results provide favorable support for WIF1 as the causative gene for ear size.

Genetics and Molecular Research 16 (2): gmr16029252 
Table 3. Normalized mRNA expression levels of four genes in Erhualian and Large White pigs.

\begin{tabular}{|c|c|c|c|}
\hline Gene & Breed & Expression level $^{1}$ & P value \\
\hline \multirow[t]{2}{*}{ WIF1 } & Erhualian & $1.02 \pm 0.14$ & \multirow[t]{2}{*}{0.0137} \\
\hline & Large White & $2.03 \pm 0.31$ & \\
\hline \multirow[t]{2}{*}{ LEMD3 } & Erhualian & $1.40 \pm 0.24$ & \multirow[t]{2}{*}{0.0545} \\
\hline & Large White & $0.77 \pm 0.19$ & \\
\hline \multirow[t]{2}{*}{$H M G A 2$} & Erhualian & $1.29 \pm 0.18$ & \multirow[t]{2}{*}{0.3136} \\
\hline & Large White & $1.07 \pm 0.11$ & \\
\hline \multirow[t]{2}{*}{ MSRB3 } & Erhualian & $1.51 \pm 0.19$ & \multirow[t]{2}{*}{0.0565} \\
\hline & Large White & $0.97 \pm 0.19$ & \\
\hline
\end{tabular}

${ }^{1} \beta$-actin was used as an endogenous control to normalize the target gene expression.

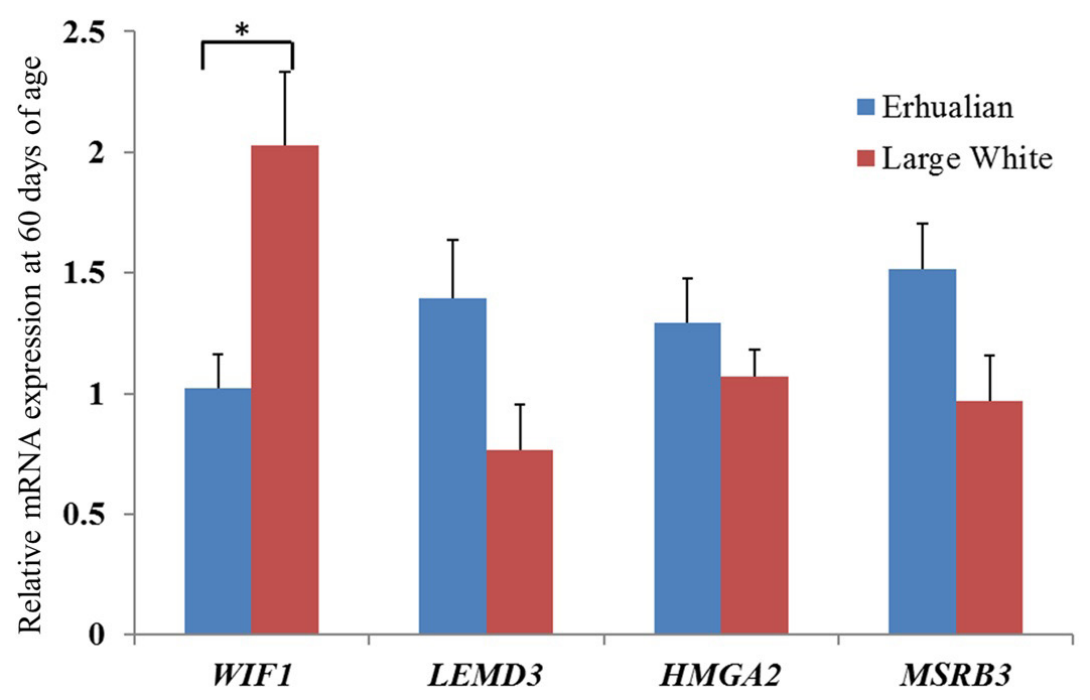

Figure 1. Normalized mRNA expression levels of WIF1, LEMD3, HMGA2, and MSRB3 in the ears of Erhualian and Large White pigs. ${ }^{*} \mathrm{P}<0.05$.

\section{$\begin{array}{llllllllllllllllll}\text { A1 } & \text { A2 } & \text { A3 } & \text { A4 } & \text { A5 } & \text { A6 } & \text { A7 } & \text { A8 } & \text { A9 } & \text { A10 } & \text { B1 } & \text { B2 } & \text { B3 } & \text { B4 } & \text { B5 } & \text { B6 } & \text { B7 } & \text { B8 }\end{array}$}

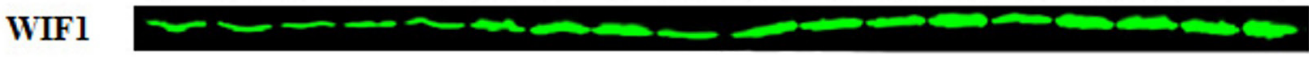

LEMD3

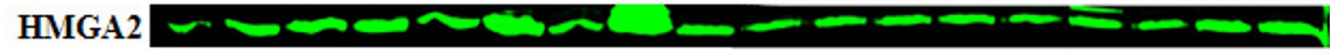

MSRB3

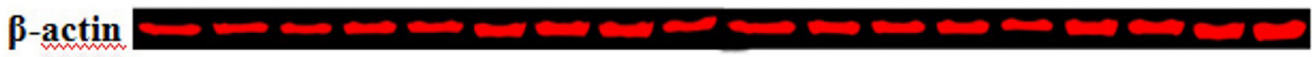

Figure 2. Protein expression levels of four genes in Erhualian and Large White pigs. $\beta$-actin was used as an endogenous control to normalize the target gene expression. Individuals A1-A10 were Erhualian pigs and individuals B1-B8 were Large White pigs.

Genetics and Molecular Research 16 (2): gmr16029252 
WIF1 and MSRB3 protein levels were significantly different in Erhualian and Large White pigs' ears

The expression levels of the four proteins in the ear tissues are shown in Figure 3 and Table 4. WIF1 was significantly more expressed in Large White than in Erhualian pigs $(\mathrm{P}<$ 0.01), whereas MSRB3 was significantly more expressed in Erhualian than in Large White pigs $(\mathrm{P}<0.05)$. There were no significant differences between the two breeds in residual protein expression. These results suggest that WIF1 and MSRB3 protein expression affect pig ear size more than HMGA2 and LEMD3 protein expression.

Table 4. Western blot analysis of four genes in Erhualian and Large White pigs.

\begin{tabular}{l|l|c|c}
\hline Gene & Breed & Expression level ${ }^{1}$ & P value \\
\hline \multirow{2}{*}{ WIFI } & Erhualian & $1.08 \pm 0.07$ & 0.0006 \\
\cline { 2 - 3 } & Large White & $1.53 \pm 0.07$ & \\
\hline \multirow{2}{*}{ LEMD3 } & Erhualian & $0.78 \pm 0.10$ & 0.0638 \\
\cline { 2 - 3 } & Large White & $0.53 \pm 0.06$ & \multirow{2}{*}{0.0659} \\
\cline { 2 - 3 } & Erhualian & $1.84 \pm 0.29$ & \\
\cline { 2 - 3 } & Large White & $1.23 \pm 0.06$ & 0.0303 \\
\cline { 2 - 3 } & Erhualian & $2.08 \pm 0.15$ & \\
\hline \multirow{2}{*}{ MSRB3 } & Large White & $1.488 \pm 0.20$ & \\
&
\end{tabular}

${ }^{1} \beta$-actin was used as an endogenous control to normalize the target gene expression.

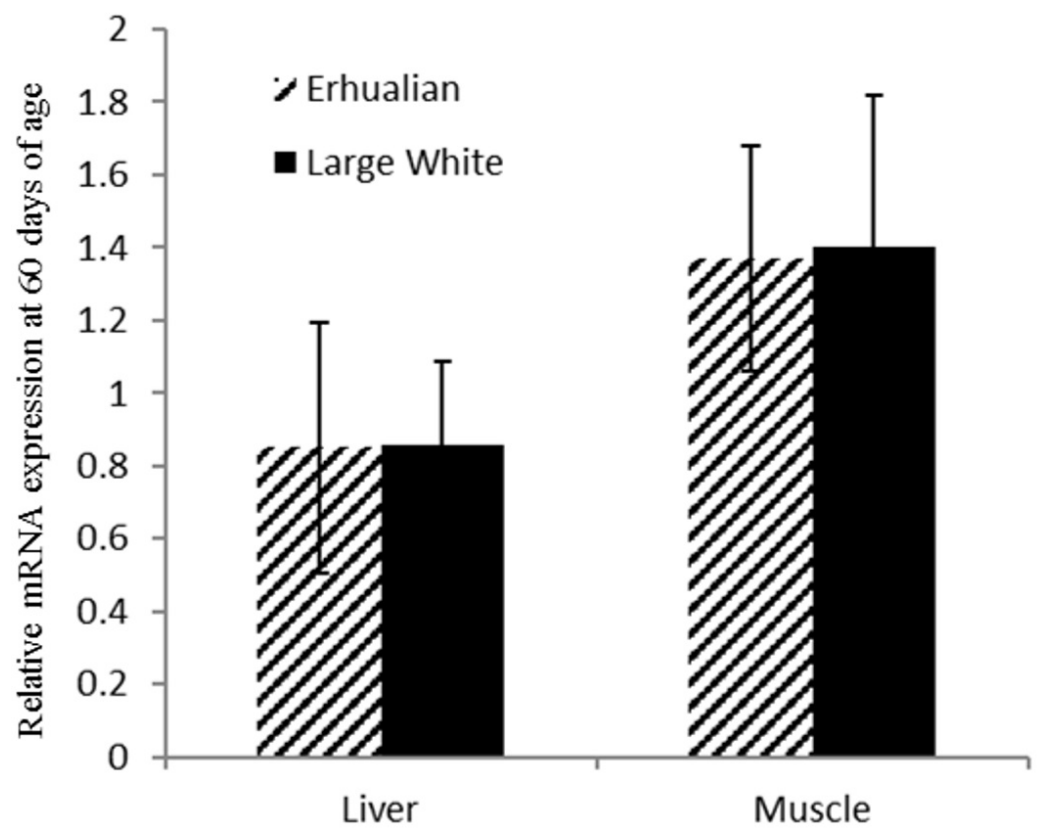

Figure 3. Normalized mRNA expression levels of WIF1 in the livers and muscles of Erhualian and Large White pigs.

\section{DISCUSSION}

In this study, two pig breeds, Erhualian and Large White, were used to examine the mRNA and protein expression levels of four candidate genes, WIF1, LEMD3, HMGA2, and

Genetics and Molecular Research 16 (2): gmr16029252 
MSRB3. In previous studies, the genomic regions on SSC5 harboring QTLs for ear size have been obtained from both White Duroc x Erhualian F2 resource populations and Large White Minzhu intercross populations (Li et al., 2012; Zhang et al., 2014). In the present study, the Erhualian pigs' ears were about $127 \mathrm{~cm}^{2}$ in area, which was 1.5 -fold larger than those of Large White pigs. With such phenotypic differences between Erhualian and Large White pigs, the two breeds are good models with which to study differences in candidate gene mRNA and protein expression levels.

Both the mRNA and protein expression levels of WIF1 were significantly higher in Large White than in Erhualian pigs. There were no significant differences in the mRNA or protein expression levels of LEMD3 or HMGA2 between the two breeds. However, the MSRB3 protein expression level was significantly higher in Erhualian than in Large White pigs. A previous study reported that MSRB3 mRNA expression is significantly higher in the ears of Minzhu pigs, which have large ears, than in the ears of Large White pigs, which have small ears (Zhang et al., 2015). In the present study, the limitation of only using two pig breeds to analyze four candidate genes for ear size was evident, and a comparison of these genes' expression levels among more pig breeds with a greater diversity in ear size is necessary to identify gene functions further. Nevertheless, the Erhualian breed has almost the largest ears among pig breeds and are obviously larger than those of Large White pigs. Therefore, we can conclude that WIF1 is the prime candidate gene for porcine ear size and morphology.

Previous studies have shown that WIF1 is a secreted protein that can directly bind with Wnts and/or Fzds to interfere with functional interactions between agonist and transmembrane receptors, and affect their activity (Hsieh et al., 1999). WIF1 can also inhibit $\beta$-catenin expression, induce human and mouse osteoblastic differentiation, and suppress osteosarcoma growth (Kansara et al., 2009). The Wnt/ $\beta$-catenin pathway can suppress chondrocyte hypertrophy and endochondral ossification in the nascent stage (Tamamura et al., 2005). WIF1 also stimulates osteoblasts and regulates bone formation (Westendorf et al., 2004), and is also expressed in the marginal periarticular perichondrium of the metacarpal (Witte et al., 2009). Loss of WIF1 expression increases sensitivity to osteoblasts (Kansara et al., 2009). Recently, some studies have reported that WIF1 interferes with the Wint-3a-mediated inhibition of chondrogenesis in embryonic chick limb bud cells (Surmann-Schmitt et al., 2009; Stock et al., 2013). Therefore, low WIF1 expression might allow the Wnt/ $\beta$-catenin pathway to increase cartilage cell proliferation during the process of outer ear growth, resulting in the large ears of Erhualian pigs.

In summary, we detected different mRNA and protein expression levels of WIF1, LEMD3, HMGA2, and MSRB3 in Erhualian pigs with large ears and Large White pigs with small ears. There were no significant differences in LEMD3 or HMGA2 mRNA or protein expression levels between the breeds. At the protein level, MSRB3 was significantly more highly expressed in Erhualian than in Large White pigs, whereas WIF1 mRNA and protein expression levels were both significantly higher in Large White than in Erhualian pigs. These results provide useful information for further functional analyses of candidate genes that influence ear size in pigs.

\section{Conflicts of interest}

The authors declare no conflict of interest.

Genetics and Molecular Research 16 (2): gmr16029252 


\section{ACKNOWLEDGMENTS}

Research supported by the Agricultural Science and Technology Innovation Program (\#ASTIP-IAS02), the National Key Technology R\&D Program of China (\#2015BAD03B02), the Earmarked Fund for Modern Agro-Industry Technology Research System, and the National Technology Program of China.

\section{REFERENCES}

Boyko AR, Quignon P, Li L, Schoenebeck JJ, et al. (2010). A simple genetic architecture underlies morphological variation in dogs. PLoS Biol. 8: e1000451. http://dx.doi.org/10.1371/journal.pbio.1000451

Duan Y, Brenig B, Wu X, Ren J, et al. (2013). The G32E functional variant reduces activity of PPARD by nuclear export and post-translational modification in pigs. PLoS One 8: e75925. http://dx.doi.org/10.1371/journal.pone.0075925

Guo XL, Looft C, Reinsch N and Ernst K (2004). [QTL mapping for ear shape based on a commercial pig population]. $Y i$ Chuan Xue Bao 31: 819-821.

Hsieh JC, Kodjabachian L, Rebbert ML, Rattner A, et al. (1999). A new secreted protein that binds to Wnt proteins and inhibits their activities. Nature 398: 431-436. http://dx.doi.org/10.1038/18899

Kansara M, Tsang M, Kodjabachian L, Sims NA, et al. (2009). Wnt inhibitory factor 1 is epigenetically silenced in human osteosarcoma, and targeted disruption accelerates osteosarcomagenesis in mice. J. Clin. Invest. 119: 837-851. http:// dx.doi.org/10.1172/JCI37175

Li P, Xiao S, Wei N, Zhang Z, et al. (2012). Fine mapping of a QTL for ear size on porcine chromosome 5 and identification of high mobility group AT-hook 2 (HMGA2) as a positional candidate gene. Genet. Sel. Evol. 44: 6. http://dx.doi. org/10.1186/1297-9686-44-6

Livak KJ and Schmittgen TD (2001). Analysis of relative gene expression data using real-time quantitative PCR and the 2(-Delta Delta C(T)) Method. Methods 25: 402-408. http://dx.doi.org/10.1006/meth.2001.1262

Ma J, Qi W, Ren D, Duan Y, et al. (2009). A genome scan for quantitative trait loci affecting three ear traits in a White Duroc x Chinese Erhualian resource population. Anim. Genet. 40: 463-467. http://dx.doi.org/10.1111/j.13652052.2009.01867.X

Ren J, Duan Y, Qiao R, Yao F, et al. (2011). A missense mutation in PPARD causes a major QTL effect on ear size in pigs. PLoS Genet. 7: e1002043. http://dx.doi.org/10.1371/journal.pgen.1002043

Rothschild MF and Ruvinsky A (1998). The genetics of the pig. CAB International, Oxon, UK.

SAS (Statistical Analysis System) (2001). SAS/STAT user's guide: statistics release 8.2. SAS Institute Inc., Cary, NC.

Stock M, Böhm C, Scholtysek C, Englbrecht M, et al. (2013). Wnt inhibitory factor 1 deficiency uncouples cartilage and bone destruction in tumor necrosis factor $\alpha$-mediated experimental arthritis. Arthritis Rheum. 65: 2310-2322. http:// dx.doi.org/10.1002/art.38054

Surmann-Schmitt C, Widmann N, Dietz U, Saeger B, et al. (2009). Wif-1 is expressed at cartilage-mesenchyme interfaces and impedes Wnt3a-mediated inhibition of chondrogenesis. J. Cell Sci. 122: 3627-3637. http://dx.doi.org/10.1242/ jcs.048926

Tamamura Y, Otani T, Kanatani N, Koyama E, et al. (2005). Developmental regulation of Wnt/beta-catenin signals is required for growth plate assembly, cartilage integrity, and endochondral ossification. J. Biol. Chem. 280: 1918519195. http://dx.doi.org/10.1074/jbc.M414275200

Vaysse A, Ratnakumar A, Derrien T, Axelsson E, et al.; LUPA Consortium (2011). Identification of genomic regions associated with phenotypic variation between dog breeds using selection mapping. PLoS Genet. 7: e1002316. http:// dx.doi.org/10.1371/journal.pgen.1002316

Wei WH, de Koning DJ, Penman JC, Finlayson HA, et al. (2007). QTL modulating ear size and erectness in pigs. Anim. Genet. 38: 222-226. http://dx.doi.org/10.1111/j.1365-2052.2007.01591.x

Westendorf JJ, Kahler RA and Schroeder TM (2004). Wnt signaling in osteoblasts and bone diseases. Gene 341: 19-39. http://dx.doi.org/10.1016/j.gene.2004.06.044

Witte F, Dokas J, Neuendorf F, Mundlos S, et al. (2009). Comprehensive expression analysis of all Wnt genes and their major secreted antagonists during mouse limb development and cartilage differentiation. Gene Expr. Patterns 9: 215223. http://dx.doi.org/10.1016/j.gep.2008.12.009

Zhang L, Liang J, Luo W, Liu X, et al. (2014). Genome-wide scan reveals LEMD3 and WIF1 on SSC5 as the candidates for porcine ear size. PLoS One 9: e102085. http://dx.doi.org/10.1371/journal.pone.0102085

Genetics and Molecular Research 16 (2): gmr16029252 
Zhang Y, Liang J, Zhang L, Wang L, et al. (2015). Porcine methionine sulfoxide reductase B3: molecular cloning, tissuespecific expression profiles, and polymorphisms associated with ear size in Sus scrofa. J. Anim. Sci. Biotechnol. 6: 60. http://dx.doi.org/10.1186/s40104-015-0060-x

Zhang ZG, Li BD and Chen XH (1986). Pig breeds in China. Shanghai Scientific and Technical Publisher, Shanghai. 